\title{
A Study of Soft Skills among Polytechnic Students
}

\author{
Isdawati Ismail, Abdul Razaq Ahmad, Mohd Mahzan Awang \\ Faculty of Education, The National University of Malaysia, Bangi, Malaysia \\ Email:razaq@ukm.edu.my
}

How to cite this paper: Ismail, I., Ahmad, A.R. and Awang, M.M. (2017) A Study of Soft Skills among Polytechnic Students. Open Journal of Social Sciences, 5, 295-311. https://doi.org/10.4236/jss.2017.58025

Received: August 7, 2017

Accepted: August 27, 2017

Published: August 30, 2017

Copyright $\odot 2017$ by authors and Scientific Research Publishing Inc. This work is licensed under the Creative Commons Attribution International License (CC BY 4.0).

http://creativecommons.org/licenses/by/4.0/ (c) (i) Open Access

\begin{abstract}
The purpose of this study is to examine the differences of soft skills practices based on demographic including gender, department of studies and locations. Soft skills in this study refer to personality development, communication skills, management skills, leadership skills, writing skills and professional ethics. This survey was conducted in Malaysia which involved 480 Polytechnic students from the northern zone $(n=120)$, the southern zone, $(n=120)$, the eastern zone, $(n=120)$, and Central zone $(n=120)$. Data were collected using a questionnaire that was analyzed using SPSS version 22.0 software comprising descriptive statistics (mean and standard deviation) and inferential statistics (one way MANOVA). Overall, results demonstrated that the levels of soft skills' module implementation in polytechnic in terms of personal development, communication skills, management skills, leadership skills, writing skills and professional ethics from the students' perspective is at a moderate level. MANOVA test showed that there was a significant difference based on the department of studies and zones. Meanwhile, there was no significant difference of soft skills based on the gender. Hence, the number of dialogue sessions with industry and relevant agencies need to be improved so that the industry requirement as a stakeholder can be met and indirectly enhanced the marketability value of the polytechnic students.
\end{abstract}

\section{Keywords}

Soft Skills, Polytechnics, Personality Development, Communication Skills, Management Skills, Leadership Skills, Writing Skills and Professional Ethics, Demographic

\section{Introduction}

Educational institutions are seen to play a role in developing the human capital 
that the country needed by giving early exposure to students on technical skills as well as soft skills. Soft skills are a set of skills aiming to complete the development of human capital in terms of intellectual, spiritual, emotional and physical basis on firm beliefs and believe in God (Annamalai, Othman \& Abdullah, 2012) [1]. Nizer (2005) [2] elaborated that soft skills such as critical and creative thinking skills, problem solving skills, communication skills, group work skills should be mastered and practiced by all students in higher institutions. Soft skills are essential in providing students to face the real-working environment. This is supported by Ai-Hwa (2005) [3] that stated the application of soft skills is required to enable a graduate to play a more effective role in the real working world. At schools and higher learning institutions levels, the generic skills subject has been taught across the curriculum. At the higher learning institution, the Ministry of Higher Education (KPT) also provides a soft skills module to be implemented at colleges or universities. There will be a loss for the country if the country's assets, which is, youths are still looking for a job without mastering any skills. The needs for a quality human capital, competitive and ambitious are indispensable for the country. Research by Ramlee (2002) [4] found that graduates from technical and vocasional school were less skilled and did not get their desired job. In addition, this study also showed the technical and vocational training faces challenges in providing the youth with positive work attitudes and employability skills. Emphasis on soft skills aspects among students is not only to fulfill the requirements of the institution, but also to produce first-class human capital that are competitive, competent, rugged and flexible in order to face the working environment (Ahmad Anuar \& Esa, 2010) [5]. In contrast to Quek (2005) [6] study found that employers are highly critical on soft skills in finding prospective employees. Both studies have shown that employers are emphasising on soft skills apart from the graduates' existing knowledge. Therefore, graduates should master and equip themselves with soft skills so that they can continue to carry the nation's excellence.

\subsection{Purpose of the Study}

The purpose of this study is to identify the level of soft skills practices in the aspects of personality development, communication skills, management skills, leadership skills, writing skills and professional ethics from students' perspective. This study also examines the levels of those aspects and the differences based on students' gender, department of studies and locations.

\subsection{Soft Skills Course at Polytechnic}

In line with the goals of the Ministry of Higher Education who want to make soft skills as an essential skill in the implementation of teaching and learning of each course at IPT, in 2009, a Soft Skills Course was introduced at Polytechnics nationwide. This soft skills course was implemented as a core course at Polytechnic for all departments. Each Polytechnic student is required to take the course be- 
fore they go for industrial training.

This soft skills course is based on content comprising Six-dimensional Soft Skills. All of these six soft skills can create competitiveness and benefits the Polytechnic graduates in the job market as well as excellence in the technical field involved in Polytechnics. This course is conducted for Semester III students for all departments for 15-weekperiod with 2-hour credit each week which is special course namely US 101: Soft skills taught by lecturers in their respective departments. Continuous assessment in various approaches and formats specified by the Ministry of Higher Education used to assess the level of soft skills among students through this course.

The course components taught give a higher emphasize on assessment in the form of quizzes, projects, peer assessment, effective presentation methods, groups assessment and writing quality. Lecturers are also given guidance in carrying out soft skills in teaching and learning by involving various forms of activities such as role play, brainstorming, public speaking and writing skills whichs include minute paper, paperworks and project papers.

\subsection{Teaching and Learning Practices in Implementing Soft Skills}

Erdiana Timmong (2006) [7] study shows that the mean value is at the low level, which is 1.87 for the soft skills application among educators group in Faculty of Education using various teaching methods. Nevertheless, there is a positive response and the respondents which agree that lecturers apply soft skills either directly or indirectly in the lecture room. Therefore, assumption can be made from Erdiana's study which shows that the low level of soft skills among students may be due to the lack of the generic skills application by the educators from the Faculty of Education.

There are also studies on generic skills aspects such as communication skill, group working skills, problem solving skills, flexibility and so on. The finding in (Yasmin, Md Adnan \& Anuar (2012) [8] shows that soft skills among students are at a high level. Furthermore, study by Ahmad Esa, Jailani \& Fadilah (2011)

[9] found that soft skills in university graduates' attributes were also at a high level.

Soft skills or generic skills are the added value for higher institution or Polytechnics graduate to compete and have the required advatages to score a place in in the job market. Among the generic skills developed in the context of learning in Higher Learning Institute and forming students' self-transformation in entering the job field and social community namely: communication skills, teamwork skill, problem solving, self-adaptation, lifelong learning, self esteem as well as ethics and integrity.

\section{Methodology}

This study uses survey method through questionnaire as research instrument. This questionnaire (refer Appendix) uses 5 points Likert scale. This study con- 
sists of 40 items comprising of Part A: Demographic Information and Part B: Soft skills among students referring to personality development (11 questions), communication skills (7 questions), management skills (5 questions), leadership skills (6 questions), writing skills (5 questions) and professional ethics (6 questions). The pilot study results for the whole construct are at a high reliability level between 0.837 and 0.747 and can be used in actual studies. SPSS software version 22.0 was used to analyse the data.

Sample selection was based on Krecjie \& Morgan (1970) [10] sampling schedule involving a total of 480 polytechnic students from the northern zone $(\mathrm{n}=$ $120)$, the southern zone, $(n=120)$, the eastern zone $(n=120)$, and Central zone $(\mathrm{n}=120)$. In terms of gender, $277(57.7 \%)$ were male and 203 were female (42.3\%), while for the department of studies, 160 (33.3\%) were the students from Civil Engineering department, 160 (33.3\%) were Electronic and Electrical Engineering students and 160 (33.3\%) Mechanical Engineering Department students. Next, based on the zone, 120 (25.0\%) were students from Southern zone, 120 (25.0\%) from Central zone, 120 (25.0\%) were Eastern zone students and 120 (25.0\%) were North zone students. The means score interpretation in this study as follow: 1.00 - 2.00 (low), 2.01 - 3.00 (moderately-low), 3.01 - 4.00 (moderately-high) and $4.01-5.00$ (high) (Nunnaly, 1978) [11].

\section{Results}

\subsection{The Levels of Soft Skills Practices}

The levels of soft skills practices in polytechnics in terms of personality development, communication skills, management skills, leadership skills, writing skills and professional ethics based on the students' perspective as a whole is shown in Table 1 below.

Table 1 shows that the student's perspective of soft skills practices in polytechnics in terms of Management Skills has the highest mean for moderately high level. Next is followed by Professional Ethics and Personal Development which are both at moderately high level. While the lowest mean of moderately

Table 1. Levels of soft skills practices in polytechnics in term of personality development, communication skills, management skills, leadership skills, writing skills and professional ethics from students' perspective.

\begin{tabular}{ccccc}
\hline No. & Soft skills practices & Mean & $\begin{array}{r}\text { Standard } \\
\text { Deviation }\end{array}$ & Level \\
\hline 1 & Personality Development & 3.87 & 0.53 & Moderately High \\
2 & Communication skill & 3.59 & 0.45 & Moderately High \\
3 & Management skill & 3.91 & 0.53 & Moderately High \\
4 & Leadership skill & 3.84 & 0.56 & Moderately High \\
5 & Writing skill & 3.70 & 0.57 & Moderately High \\
6 & Professional Ethics & 3.89 & 0.55 & Moderately High \\
& Overall Mean for Soft Skills Practices & 3.80 & 0.12 & Moderately High \\
\hline
\end{tabular}


high level is leadership skills followed by writing skills and communication skills.

\subsection{Differences of Soft Skill Practices Based on Gender}

MANOVA analysis was conducted to identify the difference of soft skills practices basedongender perspective.

Table 2 shows that there is no significant difference of soft skills practices based on gender. The differences of soft skills practices in terms of personal development, communication skills, management, leadership, writing and professional ethics in polytechnics from students' perspective based on gender in more detail is analysed using MANOVA which can be seen in Table 3 below.

Table 3 shows that there is a significant difference of soft skills practices in terms of personality development from the students' perspective based on gender. In terms of mean, female students $($ mean $=4.49)$ have a perspective on higher evaluation of personality development as compared to the male students (mean $=4.37)$.

\subsection{The Differences of Soft Skills Practices Based on Department of Studies}

MANOVA analysis was carried out to identify the differences of soft skills

Table 2. Wlilks' Lambda differences of soft skills practices based on genders.

\begin{tabular}{cccccc}
\hline Effect & $\begin{array}{c}\text { Wilks' } \\
\text { Lambda } \\
\text { Value }\end{array}$ & FValue & $\begin{array}{c}\text { DF } \\
\text { intergroup }\end{array}$ & DFintragroup & Sig \\
\hline Soft Skills Practices & 0.976 & 1.923 & 1 & 478 & 0.075 \\
\hline
\end{tabular}

Table 3. Manova difference in the evaluation of soft skills based on gender.

\begin{tabular}{|c|c|c|c|c|c|c|c|c|c|}
\hline $\begin{array}{l}\text { Soft Skills } \\
\text { Practices }\end{array}$ & Gender & $\mathbf{N}$ & Mean & $\begin{array}{l}\text { Standard } \\
\text { Deviation }\end{array}$ & $\begin{array}{l}\text { Type III } \\
\text { Sum of } \\
\text { Squares }\end{array}$ & df & $\begin{array}{l}\text { Sum of } \\
\text { square }\end{array}$ & $\mathbf{F}$ & Sig. \\
\hline \multirow{2}{*}{$\begin{array}{c}\text { Personality } \\
\text { Development }\end{array}$} & Male & 277 & 4.37 & 0.46 & 1.672 & 1 & 1.672 & 8.149 & 0.004 \\
\hline & Female & 203 & 4.49 & 0.44 & & & & & \\
\hline \multirow{2}{*}{$\begin{array}{c}\text { Communication } \\
\text { skill }\end{array}$} & Male & 277 & 4.26 & 0.55 & 1.896 & 1 & 1.896 & 7.290 & 0.007 \\
\hline & Female & 203 & 4.38 & 0.45 & & & & & \\
\hline \multirow{2}{*}{ Management skill } & Male & 277 & 4.27 & 0.55 & 1.111 & 1 & 1.111 & 3.783 & 0.052 \\
\hline & Female & 203 & 4.36 & 0.52 & & & & & \\
\hline \multirow{2}{*}{ Leadership skill } & Male & 277 & 4.30 & 0.53 & 0.926 & 1 & 0.926 & 3.420 & 0.065 \\
\hline & Female & 203 & 4.39 & 0.50 & & & & & \\
\hline \multirow{2}{*}{ Writing skill } & Male & 277 & 4.29 & 0.59 & 0.326 & 1 & 0.326 & 1.024 & 0.312 \\
\hline & Female & 203 & 4.34 & 0.53 & & & & & \\
\hline \multirow[t]{2}{*}{ Professional Ethics } & Male & 277 & 4.34 & 0.50 & 0.578 & 1 & 0.578 & 2.425 & 0.120 \\
\hline & Female & 203 & 4.41 & 0.47 & & & & & \\
\hline
\end{tabular}


practices based on department of studies. The results of Manova analysis can be seen in Table 4 below.

Table 4 shows that there is a significant difference of soft skills practices based on the department of studies. More detailed analysis on the difference in each domain of soft skills practices in terms of personal development, communication skills, management, leadership, writing skill and professional ethics in polytechnics from students' perspective based on department of studies using MANOVA can be seen in Table 5 below.

Table 5 shows that there is a significant difference of soft skill implementation in terms of personal development, communication skills, leadership skills, and soft skills from students' perspective based on department of studies with sig = 0.000 ( $p<0.05)$. Meanwhile, there is no significant difference of soft skills implementation in terms of professional management skills and ethics with sig $=$

Table 4. Wlilks' Lambda difference of soft skills practices based on department of studies.

\begin{tabular}{cccccc}
\hline Effect & $\begin{array}{c}\text { Wilks' } \\
\text { Lambda } \\
\text { Value }\end{array}$ & ValueF & $\begin{array}{c}\text { DF } \\
\text { Intergroup }\end{array}$ & DFintragroup & Sig \\
\hline Soft skills practices & 0.927 & 3.051 & 1 & 477 & 0.000 \\
\hline
\end{tabular}

Table 5. Manova difference in the soft skills practices in polytechnics from the perspective of students based on the department of studies.

\begin{tabular}{|c|c|c|c|c|c|c|c|c|c|}
\hline $\begin{array}{l}\text { Soft Skills } \\
\text { Practices }\end{array}$ & $\begin{array}{l}\text { Department } \\
\text { of Studies }\end{array}$ & $\mathbf{N}$ & Mean & $\begin{array}{l}\text { Standard } \\
\text { Deviation }\end{array}$ & $\begin{array}{l}\text { Type III } \\
\text { Sum of } \\
\text { Squares }\end{array}$ & df & $\begin{array}{l}\text { Sum of } \\
\text { square }\end{array}$ & $\mathbf{F}$ & Sig. \\
\hline \multirow{3}{*}{$\begin{array}{c}\text { Personality } \\
\text { Development }\end{array}$} & Civil & 160 & 4.50 & 0.41 & 1.400 & 2 & 0.700 & 3.396 & 0.034 \\
\hline & Electric & 160 & 4.40 & 0.53 & & & & & \\
\hline & Mechanical & 160 & 4.37 & 0.41 & & & & & \\
\hline \multirow{3}{*}{$\begin{array}{l}\text { Communication } \\
\text { skill }\end{array}$} & Civil & 160 & 4.45 & 0.43 & 5.598 & 2 & 2.799 & 11.070 & 0.000 \\
\hline & Electric & 160 & 4.30 & 0.50 & & & & & \\
\hline & Mechanical & 160 & 4.18 & 0.57 & & & & & \\
\hline \multirow{3}{*}{ Management skill } & Civil & 160 & 4.37 & 0.54 & 1.128 & 2 & 0.564 & 1.917 & 0.148 \\
\hline & Electric & 160 & 4.31 & 0.59 & & & & & \\
\hline & Mechanical & 160 & 4.25 & 0.50 & & & & & \\
\hline \multirow{3}{*}{ Leadership skill } & Civil & 160 & 4.46 & 0.50 & 4.301 & 2 & 2.150 & 8.134 & 0.000 \\
\hline & Electric & 160 & 4.33 & 0.52 & & & & & \\
\hline & Mechanical & 160 & 4.23 & 0.52 & & & & & \\
\hline \multirow{3}{*}{ Writing skill } & Civil & 160 & 4.45 & 0.52 & 4.656 & 2 & 2.328 & 7.514 & 0.001 \\
\hline & Electric & 160 & 4.25 & 0.57 & & & & & \\
\hline & Mechanical & 160 & 4.23 & 0.57 & & & & & \\
\hline \multirow[t]{3}{*}{ Professional Ethics } & Civil & 160 & 4.43 & 0.49 & 0.902 & 2 & 0.451 & 1.893 & 0.152 \\
\hline & Electric & 160 & 4.36 & 0.54 & & & & & \\
\hline & Mechanical & 160 & 4.33 & 0.44 & & & & & \\
\hline
\end{tabular}


$0.000(\mathrm{p}>0.05)$.

Post Hoc Tukey test was conducted to examine the differences in personal development, communication skills, leadership skills and writing skills based on the department of studies.

Table 6 shows that there is a significant difference of soft skills practices in terms of personality development from the perspective of students between the civil engineering department and the mechanical engineering department with mean difference value of mean $=0.13$ and sig $=0.033(\mathrm{p}<0.05)$. In terms of mean, civil engineering department has a perspective which is the higher evaluation product on personality development than the mechanical engineering department. There is no significant difference of soft skills practices in terms of personality development from the perspective of students in all department of studies $(\mathrm{p}>0.05)$.

Table 6. Differences in personality development, communication skills, leadership skills and writing skills based on department of studies.

\begin{tabular}{|c|c|c|c|c|c|}
\hline $\begin{array}{l}\text { Soft skills } \\
\text { practices }\end{array}$ & $\begin{array}{c}\text { (I) } \\
\text { Department }\end{array}$ & $\begin{array}{c}(\mathrm{J}) \\
\text { Department }\end{array}$ & $\begin{array}{c}\text { Mean } \\
\text { Difference (I-J) }\end{array}$ & $\begin{array}{l}\text { Standard } \\
\text { Error }\end{array}$ & Sig. \\
\hline \multirow{6}{*}{$\begin{array}{c}\text { Personality } \\
\text { Development }\end{array}$} & \multirow{2}{*}{ Civil } & Civil & 0.09 & 0.05 & 0.149 \\
\hline & & Mechanical & 0.13 & 0.05 & 0.033 \\
\hline & \multirow{2}{*}{ Electrical } & Civil & -0.09 & 0.05 & 0.149 \\
\hline & & Mechanical & 0.03 & 0.05 & 0.799 \\
\hline & \multirow{2}{*}{ Mechanical } & Civil & Civil & 0.05 & 0.033 \\
\hline & & Electrical & -0.03 & 0.05 & 0.799 \\
\hline \multirow{6}{*}{$\begin{array}{c}\text { Communication } \\
\text { skill }\end{array}$} & \multirow{2}{*}{ Civil } & Civil & 0.14 & 0.06 & 0.032 \\
\hline & & Mechanical & 0.26 & 0.06 & 0.000 \\
\hline & \multirow{2}{*}{ Electrical } & Civil & -0.14 & 0.06 & 0.032 \\
\hline & & Mechanical & 0.12 & 0.06 & 0.076 \\
\hline & \multirow{2}{*}{ Mechanical } & Civil & -0.26 & 0.06 & 0.000 \\
\hline & & Electrical & -0.12 & 0.06 & 0.076 \\
\hline \multirow{6}{*}{$\begin{array}{l}\text { Leadership } \\
\text { skill }\end{array}$} & \multirow{2}{*}{ Civil } & Electrical & 0.13 & 0.06 & 0.062 \\
\hline & & Mechanical & 0.23 & 0.06 & 0.000 \\
\hline & \multirow{2}{*}{ Electrical } & Civil & -0.13 & 0.06 & 0.062 \\
\hline & & Mechanical & 0.10 & 0.06 & 0.185 \\
\hline & \multirow{2}{*}{ Mechanical } & Civil & -0.23 & 0.06 & 0.000 \\
\hline & & Electrical & -0.10 & 0.06 & 0.185 \\
\hline \multirow{6}{*}{ Writing skill } & \multirow{2}{*}{ Civil } & Electrical & $0.1975^{\star}$ & 0.06 & 0.005 \\
\hline & & Mechanical & $0.2187^{*}$ & 0.06 & 0.001 \\
\hline & \multirow{2}{*}{ Electrical } & Civil & -0.20 & 0.06 & 0.005 \\
\hline & & Mechanical & 0.02 & 0.06 & 0.938 \\
\hline & \multirow{2}{*}{ Mechanical } & Civil & -0.22 & 0.06 & 0.001 \\
\hline & & Electrical & -0.02 & 0.06 & 0.938 \\
\hline
\end{tabular}


There was a significant difference in the soft skills practices in terms of communication skills from the students' perspective between the civil engineering department and the electrical engineering department with mean difference value of mean $=0.14$ and sig $=0.032(\mathrm{p}<0.05)$. In terms of mean, the civil engineering department has a perspective that is the soft skill practices is higher on the aspect of communication skills than the electrical engineering department. There was a significant difference in the soft skills practices in terms of communication skills from the perspective of students between the civil engineering department and the mechanical engineering department with mean difference, value of mean $=0.26$ and sig $=0.000(\mathrm{p}<0.05)$. The civil engineering department has a higher mean score in the terms of communication skills compared to mechanical engineering department. There was no significant difference of soft skills practices in terms of communication skills from the students' perspective of based on department of studies ( $\mathrm{p}>0.05)$.

There is a significant difference of soft skills implementation in terms of leadership skills from the perspective of students between the public department of studies and department of mechanical with mean difference of mean $=0.23$ and sig $=0.000(\mathrm{p}<0.05)$. In terms of mean the civil engineering department has a higher perspective interm of leadership skill as compared to the mechanical engineering department. There is no significant difference in the soft skills practices in terms of leadership skills from the students' perspective based on department of studies $(\mathrm{p}>0.05)$.

There is a significant difference of soft skills practices in terms of writing skills from the perspective of students from the civil engineering department and the electrical engineering department with mean difference value $=0.20$ and sig $=$ 0.005 ( $p$ < 0.05). In term of mean, the civil engineering department has a higher literacy skill than the electrical engineering department. There was also a significant difference of the soft skills implementation in terms of writing skills from the perspective of students from civil engineering department and mechanical engineering department with mean difference value of mean $=0.22$ and sig $=0.001(\mathrm{p}<0.05)$. In terms of mean, the civil engineering department has a higher perspective in literacy skills as compared to the mechanical engineering department. There was no significant difference in the soft skills practices in terms of writing skills from the perspective of students based on department of studies $(\mathrm{p}>0.05)$.

\subsection{The Differences of Soft Skills Based on the Locations}

MANOVA analysis was carried out to identify the differences of soft skills based on the zone.

Manova analysis remain to be used to analyse the difference of soft skills impelementation in polytechnic from students' perspective based on zone due to the large sample size involved (Pallant, 2007). The results of Manova analysis can be seen in Table 7 . 
Table 8 shows that there is a significant difference of soft skills practices in polytechnics from the students' perspective based on zones. The differences on soft skills application in terms of personal development, communication skills, management, leadership, writing and professional ethics in polytechnics from students' perspective based on zone is presented below:

Table 8 shows that there is a significant difference of the application of soft skills in terms of personality development, management skills, writing skills and

Table 7. Wlilks' Lambda difference of soft skills application in polytechnic from students' perspective based on the zone.

\begin{tabular}{cccccc}
\hline Effect & $\begin{array}{c}\text { Wilks' } \\
\text { Lambda } \\
\text { Value }\end{array}$ & $\begin{array}{c}\text { F } \\
\text { Value }\end{array}$ & $\begin{array}{c}\text { DF } \\
\text { Intergroup }\end{array}$ & $\begin{array}{c}\text { DF } \\
\text { intragroup }\end{array}$ & Sig \\
\hline Soft skills practices & 0.927 & 3.051 & 1 & 477 & 0.000 \\
\hline
\end{tabular}

Table 8. Manova difference of soft skills practices based on zones.

\begin{tabular}{|c|c|c|c|c|c|c|c|c|c|}
\hline $\begin{array}{l}\text { Soft skills } \\
\text { practices }\end{array}$ & Zone & $\mathrm{N}$ & Mean & $\begin{array}{l}\text { Standard } \\
\text { Deviation }\end{array}$ & $\begin{array}{l}\text { Type III } \\
\text { Sum of } \\
\text { Squares }\end{array}$ & $\mathrm{df}$ & $\begin{array}{l}\text { Sum of } \\
\text { square }\end{array}$ & $\mathrm{F}$ & Sig. \\
\hline \multirow{4}{*}{$\begin{array}{c}\text { Personality } \\
\text { Development }\end{array}$} & South & 120 & 4.48 & 0.33 & 1.807 & 3 & 0.602 & 2.928 & 0.033 \\
\hline & Central & 120 & 4.47 & 0.45 & & & & & \\
\hline & East & 120 & 4.32 & 0.50 & & & & & \\
\hline & North & 120 & 4.42 & 0.51 & & & & & \\
\hline \multirow{4}{*}{$\begin{array}{l}\text { Communication } \\
\text { skill }\end{array}$} & South & 120 & 4.34 & 0.38 & 0.500 & 3 & 0.167 & 0.631 & 0.595 \\
\hline & Central & 120 & 4.26 & 0.55 & & & & & \\
\hline & East & 120 & 4.34 & 0.43 & & & & & \\
\hline & North & 120 & 4.30 & 0.66 & & & & & \\
\hline \multirow{3}{*}{ Management skill } & South & 120 & 4.41 & 0.42 & 2.785 & 3 & 0.928 & 3.185 & 0.024 \\
\hline & Central & 120 & 4.26 & 0.55 & & & & & \\
\hline & East & 120 & 4.21 & 0.57 & & & & & \\
\hline \multirow{4}{*}{ Leadership skill } & North & 120 & 4.36 & 0.61 & & & & & \\
\hline & South & 120 & 4.36 & 0.39 & 0.965 & 3 & 0.322 & 1.182 & 0.316 \\
\hline & Central & 120 & 4.31 & 0.51 & & & & & \\
\hline & East & 120 & 4.28 & 0.54 & & & & & \\
\hline \multirow{4}{*}{ Writing skill } & North & 120 & 4.40 & 0.61 & & & & & \\
\hline & South & 120 & 4.36 & 0.44 & 2.356 & 3 & 0.785 & 2.491 & 0.060 \\
\hline & Central & 120 & 4.21 & 0.56 & & & & & \\
\hline & East & 120 & 4.28 & 0.59 & & & & & \\
\hline \multirow{5}{*}{$\begin{array}{l}\text { Professional } \\
\text { Ethics }\end{array}$} & North & 120 & 4.38 & 0.64 & & & & & \\
\hline & South & 120 & 4.38 & 0.40 & 4.051 & 3 & 1.350 & 5.820 & 0.001 \\
\hline & Central & 120 & 4.37 & 0.46 & & & & & \\
\hline & East & 120 & 4.24 & 0.56 & & & & & \\
\hline & North & 120 & 4.50 & 0.50 & & & & & \\
\hline
\end{tabular}


professional ethics from the perspective of students based on sig $=(p<0.05)$. The soft skills practices in terms of communication skills and leadership skills shows there is no significant difference based on zones.

Post Hoc Tukey test is conducted to analyse the differences in personality development, management skills and professional ethics based on zones.

Table 9 shows that there is a significant difference on the application of soft

Table 9. Pos Hoc Tukeyresults on the differences in professional development, management skills and professional ethics based on zones.

\begin{tabular}{|c|c|c|c|c|c|}
\hline Soft skills practices & (I) Zone & (J) Zone & $\begin{array}{c}\text { Mean } \\
\text { Differences (I-J) }\end{array}$ & $\begin{array}{c}\text { Standard } \\
\text { Error }\end{array}$ & Sig. \\
\hline \multirow{17}{*}{ Personality Development } & \multirow{3}{*}{ South } & Central & 0.01 & 0.06 & 0.998 \\
\hline & & East & 0.16 & 0.06 & 0.041 \\
\hline & & North & 0.05 & 0.06 & 0.788 \\
\hline & \multirow{3}{*}{ Central } & South & -0.01 & 0.06 & 0.998 \\
\hline & & East & 0.14 & 0.06 & 0.066 \\
\hline & & North & 0.04 & 0.06 & 0.876 \\
\hline & \multirow{3}{*}{ East } & South & -0.16 & 0.06 & 0.041 \\
\hline & & Central & -0.14 & 0.06 & 0.066 \\
\hline & & North & -0.10 & 0.06 & 0.314 \\
\hline & \multirow{3}{*}{ North } & South & -0.05 & 0.06 & 0.788 \\
\hline & & Central & -0.04 & 0.06 & 0.876 \\
\hline & & East & 0.10 & 0.06 & 0.314 \\
\hline & \multirow{3}{*}{ South } & Central & 0.15 & 0.07 & 0.153 \\
\hline & & East & 0.19 & 0.07 & 0.031 \\
\hline & & North & 0.05 & 0.07 & 0.900 \\
\hline & & South & -0.15 & 0.07 & 0.153 \\
\hline & Central & East & 0.05 & 0.07 & 0.917 \\
\hline \multirow{6}{*}{ Management skill } & & North & -0.10 & 0.07 & 0.493 \\
\hline & & South & -0.19 & 0.07 & 0.031 \\
\hline & East & Central & -0.05 & 0.07 & 0.917 \\
\hline & & North & -0.14 & 0.07 & 0.169 \\
\hline & & South & -0.05 & 0.07 & 0.900 \\
\hline & North & Central & 0.10 & 0.07 & 0.493 \\
\hline \multirow{13}{*}{ Professional Ethics } & & East & 0.14 & 0.07 & 0.169 \\
\hline & \multirow{3}{*}{ South } & Central & 0.01 & 0.06 & 1.000 \\
\hline & & East & 0.14 & 0.06 & 0.128 \\
\hline & & North & -0.12 & 0.06 & 0.194 \\
\hline & \multirow{3}{*}{ Central } & South & -0.01 & 0.06 & 1.000 \\
\hline & & East & 0.13 & 0.06 & 0.155 \\
\hline & & North & -0.13 & 0.06 & 0.162 \\
\hline & \multirow{3}{*}{ East } & South & -0.14 & 0.06 & 0.128 \\
\hline & & Central & -0.13 & 0.06 & 0.155 \\
\hline & & North & -0.26 & 0.06 & 0.000 \\
\hline & \multirow{3}{*}{ North } & South & 0.12 & 0.06 & 0.194 \\
\hline & & Central & 0.13 & 0.06 & 0.162 \\
\hline & & East & 0.26 & 0.06 & 0.000 \\
\hline
\end{tabular}


skills in terms of personality development from the perspective of students between the south central zone and the east zone with mean difference of mean = 0.16 and sig $=0.041(\mathrm{p}<0.05)$. In terms of mean, it shows that the southern zone has a higher perspective on product evaluation in term of personality development than the eastern zone. There was no significant difference in the soft skills practicess in term of personality development from the students' perspective based on zones ( $p>0.05)$.

There was a significant difference in the soft skills practicess in term of management skills from the perspective of students between the south central zone and the east zone with mean difference of mean $=0.19$ and sig $=0.031(\mathrm{p}<$ $0.05)$. From a mean point the south zone has a perspective that is higher product evaluation in term of management skills as compared to the the eastern zone. There is no significant difference on the application of soft skills in terms of management skills from the perspective of students based on zones $(p>0.05)$.

There was a significant difference in the soft skills practices in term of professional ethics from the perspective of students from the south east zone and the north zone with mean differences of mean $=-0.26$ and sig $=0.000(p<0.05)$. In terms of mean, it shows that the north zone has a higher perspective in professional ethics than the north zone. There is no significant difference in implementation of the soft skills in terms of professional ethics from the perspective of students based on zones ( $\mathrm{p}>0.05)$.

\section{Discussion}

Assessment based on gender reveals that there is a significant difference in personality development and communication skills in which female students have better personalities and communication skills than male students. This is contrary to previous study by Maclean \& Ordonez (2007) [12] which indicated in their study that male students can directly understand a concept without having to associate it with the real world. This shows the better ability of male students as compared to women. However, there is no significant difference in management skills, leadership skills, writing skills and professional ethics based on gender.

Based on department of studies, there is a significant difference of soft skills practices based on the student's perspective on the aspects of personality development, communication skills, leadership skills and writing skills where students from civil engineering department have a better personality development, communication skills, leadership skills and better writing skills as compared to the students studying at electrical engineering department and mechanical engineering department. The current findings added to the exusting knowledge on soft skills carried out by Mohd Yusof et al. (2012) [13] where it was reported that there was no significant difference in marketability skills between the students from mechanical, electrical and civil engineering departments. Past empirical studies on genders revealed a mixture of perceptions among respondents where 
Freudenberg, Brimble \& Cameron (2011) [14] reported that some elements are performed well by women compared to men. Another study by Ridzwan et al. (2017) [15] reported the differences between genders in terms of students' engagement in social activities. A study carried out by Abdul Razaq et al. (2017) [16] on genders among multi-ethnic youths revealed that female youths had a difference perceptions toward soft skills practices.

Based on the studied zones, there was a significant difference of soft skills practices from the students' perspective on the aspects of personal development, management skills and professional ethics in which students studying in the southern zone had better personality and management skills than the central, eastern and northern zones. This is parallel with the comparative study on soft skills carried out by Alfitri (2017) where there is a significant difference between zones in soft skills practices between Malaysia and Indonesia. The current study also revealed that students from the north zone have a better perception towards their professional ethics practices compared to students from other zones. This may be due to the social environmental factor where there are many industrial sectors operated surrounding the campus area. Ramlee Mustapha (2002) [4] in his study on TVET and soft skills demonstrated that there is a link between environment and soft skills implementation.

\section{Implication and Suggestion}

This study implies that a need to review the soft skills modules in polytechnic as results from the current study indicated that the levels of soft skills practices are still unsastifying. The most important part to improve the modules are communication skills, management skills, leadership skills and writing skills. The modules should be taken into account the factors of genders and the needs of students in soft skills. A flexible module and global based content should be integrated in the teaching and learning process.

Polytechnic lecturers should improve their skills on pedagogy to promote better soft skills practices among students by using various techniques and approaches. The use of ICT in teaching and learning is one of the main factors contributing to effective teaching and learning in soft skills. Blended learning should be practiced by lecturers as it combines both face-to-face techniques and online based learning. This might be able to improve soft skills practices and the capabilities in many areas among polytechnic students in Malaysia.

\section{Limitation of the Study}

The current study uses survey research design where there is a limitation to understand in details soft skills practices and how polytechnic curriculum affects the students' abilities in soft skills. The scope of the study can be expanded to various elements of soft skills where the current study just surveyed their level of soft skills. It may be needed in the future research to explore influencing factors for soft skills development. 


\section{Conclusion}

Overall, soft skills among polytechnic students require specific strategies to be improved. These include the improvement of current modules especially in terms of teaching and learning and how students involve in campus activities. As past studies recommended that the involvement of industrial partnership would improve positive environment to promote soft skills, polytechnic administration should have better partnership with various industries. Adialogue session with industry and relevant agencies need to be improved so that the industry requirement as a stakeholder can be met and indirectly enhanced the marketability value of the polytechnic students. Polytechnic lecturers are also should be encouraged to attend trainings and seminars for improving their skills and knowledge on soft skills implementation.

\section{References}

[1] Annamalai, M., Othman, A.T. and Dan Abdullah, A.G.K. (2012) Influences of Family Support in School C-Curriculum Involvement towards Students' Soft Skills Achievements. National Seminar on Public University Education Dean Ceremony, 7-8 October 2012, Universiti Teknologi Malaysia, Johor.

[2] Nizar, N. (2005) Technical Skills Personality of Graduates from National Youth Skills Institution (IKBN). Master's Thesis, Universiti Tun Hussein Onn Malaysia.

[3] Ai-Hwa, Q. (2005) Learning for the Workplace: A Case Study in Graduate Employees Generic Competencies. Journal of Workplace Learning, 17, 231-242. https://doi.org/10.1108/13665620510597185

[4] Mustapha, R. (2002) The Role of Vocational and Technical Education in the Industrialization of Malaysia as Perceived by Educator and Employers. Doctoral Dissertation, Purdue University.

[5] Ahmad Anuar, A. and Esa, A. (2010) Implementation of Soft Skills in Giat Mara Centre (PGM): A Comparative Analysis. In: Esa, A. and Mustafa, M.Z., Eds., Soft Skills: Study in Higher Institutions, BatuPahat: UTHM Publisher, 1-19.

[6] Quek (2005) Learning for the Workplace: A Case Study in Graduate Employees' Generic Competencies. Journal of Workplace Learning, 17, 231-242.

[7] Timmong, E. (2006) Case Study on Awareness Level on the Importance of Soft Skills among Students in Faculty of Education. Master's Thesis, Universiti Teknologi Malaysia.

[8] Adnan, Y.M., Daud, M.N. and Alias, A. (2012) Importance of Soft Skills for Graduates in the Real Estate Programmes in Malaysia. Journal of Surveying, Construction \& Property, 3, 1-13.

[9] Esa, A., Yunus, J.M. and Hashim, F.M.A. (2011) The Implementation of Generic Skills at Technical Schools: Comparative Analysis in Different Platform. Journal of Techno-Social, 3.

[10] Krejcie, R.V. and Morgan, D.W. (1970) Determining Sample Size for Research Activities. Educational and Psychological Measurement, 30, 607-610. https://doi.org/10.1177/001316447003000308

[11] Nunnally, J.C. (1978) Psychometric Theory. 2nd Edition, McGraw-Hill, New York.

[12] Maclean, R. and Ordonez, V. (2007) Work, Skills Development for Employability and Education for Sustainable Development. Educational Research for Policy and 
Practice, 6, 123-140. https://doi.org/10.1007/s10671-007-9017-y

[13] Mohd Yusof, H., Mustapha, R., Malik Syed Mohamad, S.A. and Seri Bunian, M. (2012) Measurement Model of Employability Skills Using Confirmatory Factor Analysis. Procedia-Social and Behavioral Sciences, 56, 348-356. https://doi.org/10.1016/j.sbspro.2012.09.663

[14] Freudenberg, B., Brimble, M. and Cameron, C. (2011) WIL and Generic Skill Development: The Development of Business Students' Generic Skills through Work integrated Learning. Asia-Pacific Journal of Cooperative Education, 12, 79-93.

[15] Ridzwan, C.R., Malik, S., Hanapi, Z., Mohamed, S., Hussain, M.A. and Shahrudin, S. (2017) Skills and Knowledge Competency of Technical and Vocational Education and Training Graduate. Asian Social Science, 13, 69-77. https://doi.org/10.5539/ass.v13n4p69

[16] Alfitri, A.R.A., Sobri, K.M. and Awang, M.M. (2017) Soft Skills among Malaysian and Indonesian Students. Research Report GG-2014-009. Faculty of Social and Political Studies, University of Sriwijaya, Indonesia. 


\section{Appendix}

\section{Response Towards}

Soft Skills Practices Among Polytechnic Students

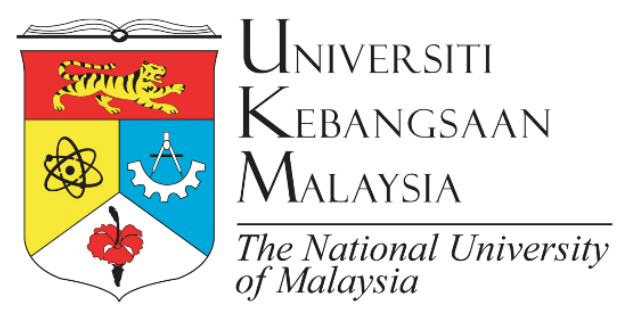

\section{Ladies and Gentleman,}

This questionnaire consists of questions to obtain feedback and responses from students on teaching and learning of soft skills in polytechnic which includes of 2 parts;

Part A: Demography of Respondents

Part B: Soft Skills practices Among Polytechnic Students

1) Personality Development

2) Communication Skills

3) Management Skills

4) Leadership Skills

5) Writing Skills

6) Professional Ethics

All information given will only be used for this research purposes only. All information are CONFIDENTIAL and will not be divulged to third party. Your kind cooperation is highly appreciated.

Part A

Respondents' Information

Please tick $(\sqrt{ })$ in the suitable box below

1. Gender

$\square$ Male

$\square$ Female

2. Department of Studies

$\square$ Mechanical Engineering

Electrical Engineering

Civil Engineering

3. Polytechnic Zones

Northern

Southern

Eastern

Central

Part B

Polytechnic Students' Soft Skills 
Please state the response based on the following scales:
1) Strongly Disagree
2) Tidak Setuju
3) Slightly Agree
4) Agree
5) Strongly Agree

\section{1) Personality Development}

\begin{tabular}{cll}
\hline No. & \multicolumn{1}{c}{ Item } & $\begin{array}{c}\text { Your } \\
\text { Response }\end{array}$ \\
\hline 1 & I always display positive personal image & \\
2 & I practice the appropriate dress code while attending an official ceremony & \\
3 & I always practice hygiene and personal health in my daily life \\
4 & I always look after myself in various situations \\
5 & I practice creative and innovative thinking skills \\
6 & I am able to control emotions in social interactions \\
7 & I often practice positive values in my daily life & \\
8 & I can distinguish in details gender sensitivity \\
9 & I always care about sexual harassment at work \\
10 & I always practice religion in everyday life \\
11 & I always respect the diversity of multiracial communities
\end{tabular}

2) Communication Skills

\begin{tabular}{cll}
\hline No. & \multicolumn{1}{c}{ Item } & $\begin{array}{c}\text { Your } \\
\text { Response }\end{array}$ \\
\hline 1 & I can communicate well according to the needs, in various situations & \\
2 & I can distinguish between facts and opinions \\
3 & $\begin{array}{l}\text { I can make a detailed explanation when making presentations based on } \\
\text { important contents in the slide }\end{array}$ \\
4 & I am able to speak fluently in public \\
5 & I am able to answer questions accurately during the interview session \\
6 & I am able to handle effective negotiation activities with various parties \\
7 & $\begin{array}{l}\text { I always use polite language in face-to-face or virtual communication with } \\
\text { friends and the community }\end{array}$ \\
\hline
\end{tabular}

\section{3) Management Skills}

\begin{tabular}{clc}
\hline No. & \multicolumn{1}{c}{ Item } & $\begin{array}{c}\text { Your } \\
\text { Response }\end{array}$ \\
\hline 1 & I always solved the problem in completing the various assignments given & \\
2 & I can always solve the problem based on the requirements \\
3 & I always manage my time effectively inside and outside of the campus & \\
4 & I can meet customers' requirements during Industrial Training \\
5 & $\begin{array}{l}\text { I can apply the procedures learned in the management for official } \\
\text { functions }\end{array}$ \\
\hline
\end{tabular}


4) Leadership Skills

\begin{tabular}{clc}
\hline No. & \multicolumn{1}{c}{ Item } & $\begin{array}{c}\text { Your } \\
\text { Response }\end{array}$ \\
\hline 1 & I lead my friends in planning a program & \\
2 & I give clear and good direction to the group members in making a program & \\
3 & I often guide, give guidance, motivation and motivation to team members & \\
4 & I often monitor and evaluate a program \\
5 & I often work well with team members \\
6 & I practice various methods of solving problems in the team \\
\hline
\end{tabular}

\section{5) Writing Skills}

\begin{tabular}{clc}
\hline No. & \multicolumn{1}{c}{ Item } & $\begin{array}{c}\text { Your } \\
\text { Response }\end{array}$ \\
\hline 1 & $\begin{array}{l}\text { I always provide paperwork, meeting minutes and official letters in the } \\
\text { correct format }\end{array}$ \\
2 & My Curriculum vitae (CV) is complete according to a professional format \\
3 & I always write a variety of official documents in the format specified \\
4 & My Bahasa Malaysia writing is very good \\
5 & My English writing is very good
\end{tabular}

\section{6) Professional Ethics Skills}

\begin{tabular}{|c|c|c|}
\hline No. & Item & $\begin{array}{l}\text { Your } \\
\text { Response }\end{array}$ \\
\hline 1 & I always obey the protocol while attending an official ceremony & \\
\hline 2 & I am always responsible for completing the assignment & \\
\hline 3 & I always practice the concept of integrity in the work & \\
\hline 4 & $\begin{array}{l}\text { I always practice a culture of abuse of power and corruption in the given } \\
\text { assignment }\end{array}$ & \\
\hline 5 & I always keep the environment everywhere I am & \\
\hline 6 & I always adhere to safety and health regulations at work & \\
\hline
\end{tabular}


Submit or recommend next manuscript to SCIRP and we will provide best service for you:

Accepting pre-submission inquiries through Email, Facebook, LinkedIn, Twitter, etc. A wide selection of journals (inclusive of 9 subjects, more than 200 journals)

Providing 24-hour high-quality service

User-friendly online submission system

Fair and swift peer-review system

Efficient typesetting and proofreading procedure

Display of the result of downloads and visits, as well as the number of cited articles Maximum dissemination of your research work

Submit your manuscript at: http://papersubmission.scirp.org/

Or contact jss@scirp.org 